\title{
Effect of Subsurface Drainage System on Maize Growth, Yield and Soil Quality
}

\author{
Arumugam Balusamy ${ }^{1,2 *}$, Chinniah Udayasoorian ${ }^{1}$ and Rajamani Jayabalakrishnan ${ }^{3}$ \\ ${ }^{1}$ Department of Environmental Science, Tamil Nadu Agricultural University, \\ Coimbatore, 641 003, India \\ ${ }^{2}$ ICAR Research Complex for NEH Region, Umiam, Meghalaya, India \\ ${ }^{3}$ Coconut Research Station, Tamil Nadu Agricultural University, Aliyar Nagar, 642 101, India \\ *Corresponding author
}

\section{A B S T R A C T}

\begin{tabular}{|c|c|}
\hline Keywords & \multirow{4}{*}{$\begin{array}{l}\text { The treated industrial wastewater has been, continuously used for crop production in the } \\
\text { water scares region of our country. Irrigation with agro-based industrial wastewater } \\
\text { (treated paper mill effluent) though it initially increased the yield of many crops, over a } \\
\text { period; it deteriorates the soil quality by addition of soluble salts in soil profile results in } \\
\text { deflocculating of soil structure, reduced infiltration and waterlogging leads to yield } \\
\text { reduction in some crops under poor management condition. A subsurface drainage } \\
\text { experiment conducted with different }(15,20 \text { and } 25 \mathrm{~m}) \text { lateral spacing in waterlogged } \\
\text { saline-alkali soil revealed that, drainage system improves the soil quality parameters, like } \\
\text { soil pH, soil EC, reduction in exchangeable cation, and reduction in exchangeable sodium } \\
\text { percentage and increased the maize yield under different lateral spacing under treated } \\
\text { effluent irrigation. }\end{array}$} \\
\hline $\begin{array}{l}\text { Subsurface } \\
\text { drainage, Late } \\
\text { spacing, Maiz } \\
\text { growth and yi } \\
\text { Saline-alkali s }\end{array}$ & \\
\hline Article Info & \\
\hline $\begin{array}{l}\text { Accepted: } \\
\text { 10 January } 2019 \\
\text { Available Online: } \\
\text { 10 February } 2019\end{array}$ & \\
\hline
\end{tabular}

\section{Introduction}

The water required for meeting agriculture, domestic, industrial and other demand indicates the need for regeneration of municipal and industrial wastewater, which is a cheap and attractive alternative to the dry areas for irrigating crops to sustain productivity. The Indian pulp and paper industry on an average, it uses $143 \mathrm{~m}^{3}$ of water to produce one ton of paper and this amount will reappear as wastewater. After proper treatment, effluent water safely used for crop production with the addition of suitable organic amendments (Udayasoorian et al., 2004; Hazarika et al., 2007). The main problems associated with irrigation using wastewater is an increase in soil exchangeable $\mathrm{Na}$, as $\mathrm{Na}$ is present in high concentrations in wastewater. The monovalent $\mathrm{Na}$ ion and its large hydration sphere further facilitate dispersion of the clay, which leads to a reduction in hydraulic conductivity, decrease in permeability, poor drainage and poor soil aeration (Halliwell et al., 2001 and Oliveira $e t$ al., 2016) will leads to waterlogging in the 
soil. An estimated 30 million ha area in the world was affected by waterlogging and salinization, while approximately an additional 80 million ha are affected to some extent (Bakker et al., 2010). The maintenance of adequate soil physical and chemical properties in waterlogged saline and alkali environment achieved by using good quality water, proper choice and the combination of soil ameliorants, good drainage and appropriate cultural practices (Grattan and Oster, 2003). The subsurface drainage system is underground artificial channels through which excess water may flow to a suitable outlet. Subsurface drainage maintains the productive capacity of soil by removing excess water, improving soil moisture, air circulation and reducing salt content and soil erosion (Chahar and Vadodaria, 2008 and Ritzema, 2009). It provides agronomical and environmental benefits, in terms of soil trafficability, field operation, prevents sediment and phosphorus loss from an agricultural field, and improves plant growth and yield in problematic soils (Ambast et al., 2007; Prasad et al., 2007; Ritzema and Schultz, 2011). Waterlogging in the field considered as one of the most important parameter, because it influences the other soil quality parameters (soil aeration, microbial activity, and nutrient availability). The unavailability of other source of good quality water necessitate the farmers to use treated wastewater and limit the choice of crop selection thereby forcing them to go for deep rooted and salt tolerant crop like coconut. The farmers now switched over to coconut based intercropping with $\mathrm{CN}$ hybrid and animal husbandry activities (Balusamy et al., 2013). Waterlogging above certain period leads to build up anaerobic condition in soil and it will deter the growth and yield of plants. So, in order to solve the problem of waterlogging and salinity in the crop root zone, the subsurface drainage system been installed at different lateral spacing's in a waterlogged saline-alkali soil in Karur District of Tamil Nadu, India.

\section{Materials and Methods}

An experiment conducted in waterlogged saline-alkali soil at Pandipalayam Village, Karur District of Tamil Nadu, India to assess the effect of different $(15,20$ and $25 \mathrm{~m})$ lateral spacing on growth, yield and soil quality of maize grown field. The lateral spacing was arrived using the Hooghouts formula based on the depth of water table, amount of water needs to be removed, hydraulic conductivity of soil, and depth to impervious layer. The subsurface drainage system installed in an area of 1.20 ha with different lateral spacing. The perforated corrugated flexible PVC pipes with a diameter of $80 \mathrm{~mm}$ used as a lateral and placed at a depth of 1.1 to $0.9 \mathrm{~m}$ from the surface. Before installation of it, the lateral covered with coconut fiber to allow the passage of water through the perforation and avoid clogging of the pores. The blind PVC pipe with a diameter of $110 \mathrm{~mm}$ has used in the main drainage, which connected with laterals to remove the water from the field. The zero chips (blue metals) were also used to as bedding material and to cover the laterals, finally the mains and laterals filled with dig out soil.

\section{Field preparation and sowing of maize}

The individual plots of 15,20 and $25 \mathrm{~m}$ lateral spacing ploughed ridges and furrows formed by adopting a spacing of $60 \mathrm{~cm}$ between the two ridges. Maize seeds (var. M 900 Gold) sown in the side of the ridges by adopting $25 \mathrm{~cm}$ spacing. The cultural practices including gap filling, thinning, weeding and plant protection measures carried out for the entire crop growth period as recommended by Tamil Nadu Agricultural University, Coimbatore. 
Details of standardization experiment with maize crop (Non-replicated trail)

$$
\begin{aligned}
& \mathrm{T}_{1}: 15 \mathrm{~m} \text { lateral spacing } \\
& \mathrm{T}_{2}: 20 \mathrm{~m} \text { lateral spacing } \\
& \mathrm{T}_{3}: 25 \mathrm{~m} \text { lateral spacing } \\
& \mathrm{T}_{4}: \text { Control (undrained field) }
\end{aligned}
$$

The representative soil samples were collected at different crop growth stages $\mathrm{Viz}$, vegetative (30 DAS), heading (60 DAS) and at harvest stage at $0-15 \mathrm{~cm}$ depth. The collected samples were analyzed for soil $\mathrm{pH}$ by potentiometry soil water suspension of 1:2.5 ratio (Jackson, 1973), electrical conductivity by conductimetry soil water suspension of 1:2.5, exchangeable sodium and potassium by a flame photometer and exchangeable calcium and magnesium by versanate titration method. The exchangeable sodium percentage worked out by using the formula given by Saxena et al., (1978).

\section{Results and Discussion}

\section{Effect of lateral spacing on soil characteristics}

The different drain spacing of 15,20 and 25 $m$ influenced the soil reaction $(\mathrm{pH})$, electrical conductivity, exchangeable cations viz., $\mathrm{Ca}$, $\mathrm{Mg}, \mathrm{Na}, \mathrm{K}$, and ESP of soil. Overall the drainage system influenced the soil physicochemical properties positively, thereby yield and growth of maize under different lateral spacing.

\section{Soil reaction $(\mathrm{pH})$}

The soil $\mathrm{pH}$ plays an important role in the availability of plant nutrients in saline-alkali soils. The presence of common acid forming cations ions viz., $\mathrm{H}^{+}, \mathrm{Fe}^{2+}$ or $\mathrm{Fe}^{3+}$ and $\mathrm{Al}^{3+}$ and base forming cations like $\mathrm{Ca}^{2+}, \mathrm{Mg}^{2+}, \mathrm{Na}^{+}$and $\mathrm{K}^{+}$are influencing the soil $\mathrm{pH}$. In the present study, the soil $\mathrm{pH}$ decreased towards crop advancement due to the removal of some of the base forming cations from the soil by drainage effluent and addition of $\mathrm{H}^{+}$in the form of $\mathrm{HCO}_{3}$ (Fig.1). Similarly, Bharambe et al., (2001), Rakesh et al., (2005) and Pradeep et al., (2005) also reported that the reduction in soil $\mathrm{pH}$ due to the removal of sodium and bicarbonate ions along with leachate water. Towards the end of the maize field experiment, the lowest soil $\mathrm{pH}$ of 8.88 was observed in the drained field with $15 \mathrm{~m}$ lateral spacing possibly as a result of the removal of much ions through drainage effluent compared to other drain spacing and undrained field.

\section{Soil Electrical conductivity (EC)}

Soil EC is a measure of the amount of salts in the soil solution, which affects crop yield, plant nutrient availability and activity of soil microorganisms. In the present study, the soil EC showed a decreasing trend (to a tune of 14.7, 14.2 and 14.0 percent in 15,20 and 20 $\mathrm{m}$ lateral spacing's, respectively compared before installation of drainage system) towards crop advancement (Fig. 2) and in undrained field it showed an increasing trend (1.29 per cent). The decrease in soil EC noticed in the drained field due to the removal of soluble salts through drainage water at different lateral spacings (Bharambe et al., (2001), Pradeep et al., (2005) and Rakesh et al., (2005). Similarly, Bahceci and Nacar (2009) reported 80 percent decrease in soil salinity within a period of 4 years and more reduction in soil salinity in top $30 \mathrm{~cm}$ of soil profile was reported by Yu et al., (2016). In the present investigation, an increase in soil EC observed in the undrained field due to the addition of a considerable quantity of soluble salts through effluent water. This was in line with the finding of several workers (Udayasoorian et al., 2003; Kumar and Chopra, 2011; Sharma et al., 2014) where they reported that effluent irrigation increased $\mathrm{EC}$ of the soil. 


\section{Soil exchangeable cations}

Exchangeable cations are those, which exchanged by a cation of an added solution. The soil exchangeable cations $\mathrm{Ca}^{2+}, \mathrm{Mg}^{2+}, \mathrm{K}^{+}$ and $\mathrm{Na}^{+}$often called the exchangeable bases, commonly occur in the soil in the order listed above (Thomas, 1982). In the present investigation, before the start of the experiment it was in the order of $\mathrm{Ca}^{2+}>\mathrm{Na}^{+}>$ $\mathrm{Mg}^{2+}>\mathrm{K}^{+}$. In drained field, the exchangeable sodium showed a decreasing trend and other cations like $\mathrm{Ca}, \mathrm{Mg}$ and $\mathrm{K}$ observed an increasing trend (Fig.3a to 3d). The paper mill effluent added a considerable amount of exchangeable cations like $\mathrm{Ca}, \mathrm{Mg}$ and $\mathrm{K}$ in soil and the content increased towards crop advancement (Hameed and Udayasoorian, 1998; Udayasoorian et al., 2003; Sharma et al., 2014 and Kumar et al., 2015). The decreasing trend of exchangeable $\mathrm{Na}^{+}$(which is basically monovalent cation) easily leached through drainage effluent under subsurface drainage system (Bharambe et al., 2001; Pradeep et al., 2005) and it showed a decreasing trend in the drained field. In the undrained field, the exchangeable cations like $\mathrm{Ca}, \mathrm{Mg}, \mathrm{Na}$ and $\mathrm{K}$ showed an increasing trend due to salt-laden effluent (Kumar et al., 2015).

\section{Exchangeable sodium percentage (ESP)}

The ESP is the amount of adsorbed sodium on the soil exchange complex expressed in percent. The monovalent nature of $\mathrm{Na}^{+}$does not attach to any nearby particle resulting in dispersion and tight arrangement of dispersed soil particle with sodium greatly reduce the infiltration and drainage in such soil. The subsurface drainage system decreased the soil exchangeable sodium percentage at the different lateral spacing in the drained field, whereas it increased in undrained filed (Fig. 4). The decrease in ESP of 15.1, 13.8 and 11.8 percent recorded at 15,20 and $25 \mathrm{~m}$ lateral spacing, respectively during the experimental period and whereas in undrained filed it increased 15.4 percent compared to initial value. The highest decrease in ESP at $15 \mathrm{~m}$ lateral spacing was recorded as a result of higher leaching of soluble salts especially $\mathrm{Na}$ through drainage water (Bharambe et al., 2001 and Pradeep et al., 2005), otherwise would have been concentrated in the soil solution and accumulated in soil layers. Similarly, Ramana Rao and Bhattacharya (2001) also reported that the effect of salt leaching is better in smaller spacing. Balusamy and Udayasoorian (2017a) observed a decrease in ESP by 42 percent over control in the drained field that received organic amendments and gypsum.

\section{Effect of lateral spacing on maize growth and yield}

The provision of subsurface drainage system in waterlogged saline-alkali soil increased the germination percentage, plant height, leaf length, leaf width and leaf area index of maize crop, due to removal of a large amount of soluble salts, waterlogging free condition and increased nutrient availability in drained field, favored the plant growth and development (Kolekar et al., 2011; Balusamy and Udayasoorian, 2017b). Similarly, Sousa et al., (2011) reported that 80 percent increase in coconut plant height after 8 months in drainage system installed field, whereas it was only 50 percent in the undrained field. The mole drainage system with $4 \mathrm{~m}$ lateral spacing increased the plant height, number of branches per plant, number of pods per plant, weight of pods per plant in groundnut (Kolekar et al., 2011).

The presence of high concentration of soluble salts in the soil, poor aeration, and poor nutrient availability at high $\mathrm{pH}$ except for specific nutrients like $\mathrm{P}$, coupled with poor quality effluent water in undrained field limits 
the growth and development of maize leading to poor germination and growth characteristics. This was supported by Kumar et al., (2010), who observed that high concentration of $\mathrm{Na}, \mathrm{CO}_{3}, \mathrm{HCO}_{3}$ in the paper mill effluent decreased the bulk density, water holding capacity due to deflocculation of soil by the high concentration of sodium and it adversely affect the germination and plant growth.

Fig.1 Effect of lateral spacings on soil $\mathrm{pH}$ in the subsurface drainage system

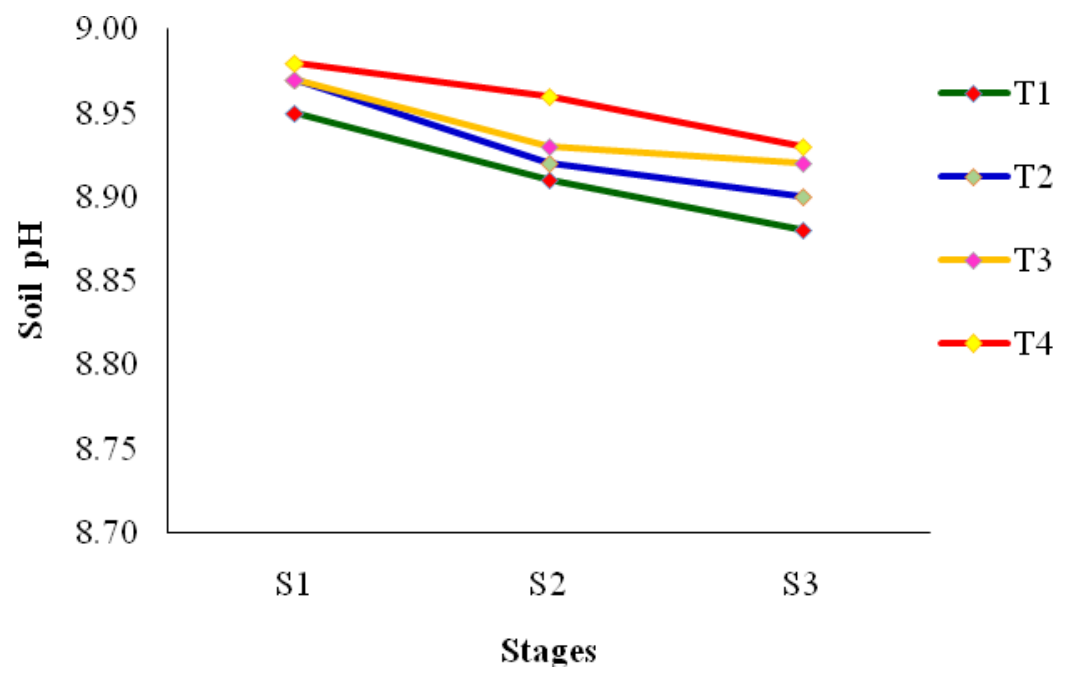

Fig.2 Effect of lateral spacing on soil EC $\left(\mathrm{dS} \mathrm{m}^{-1}\right)$ in the subsurface drainage system

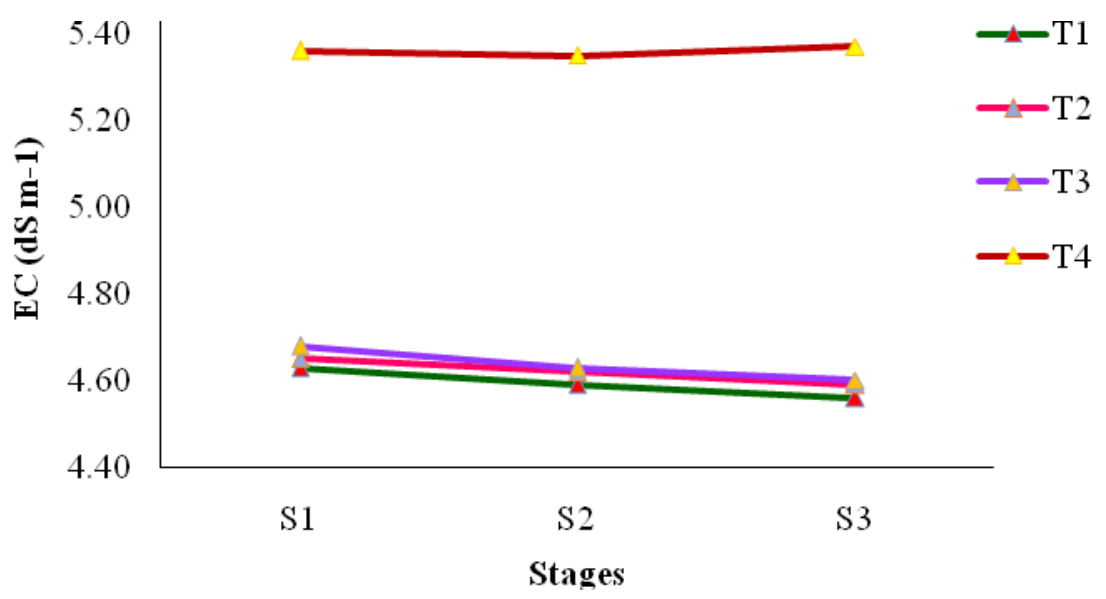

( $\mathrm{S}_{1}: 30$ DAS; $\mathrm{S}_{2}-60$ DAS; $\mathrm{S}_{3}$-at harvest stage) 
Fig.3 Effect of lateral spacing on soil exchangeable $\mathrm{Na}, \mathrm{Ca}, \mathrm{Mg}$ and $\mathrm{K}$ in the subsurface drainage system

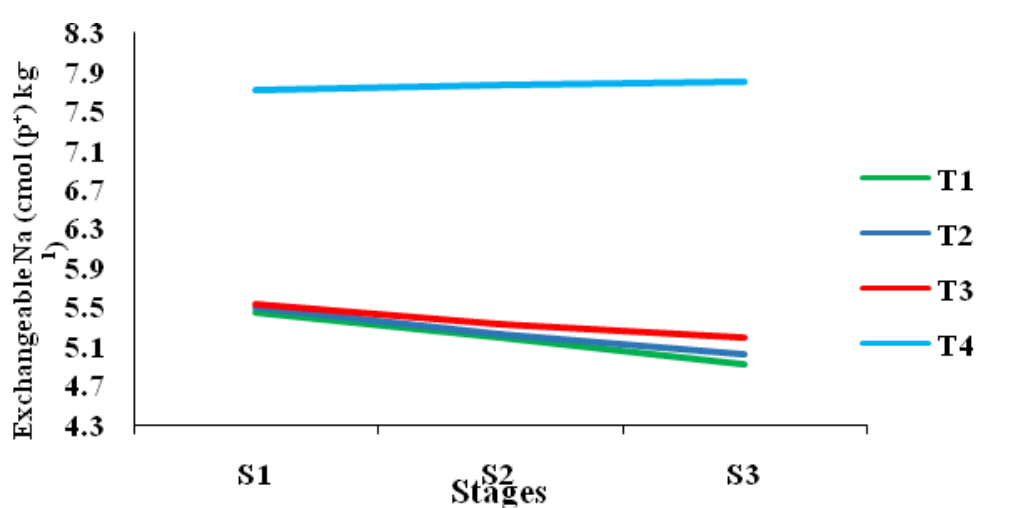

Fig.3a Exchangeable $\mathrm{Na}\left(\mathrm{cmol}\left(\mathrm{p}^{+}\right) \mathrm{kg}^{-1}\right)$

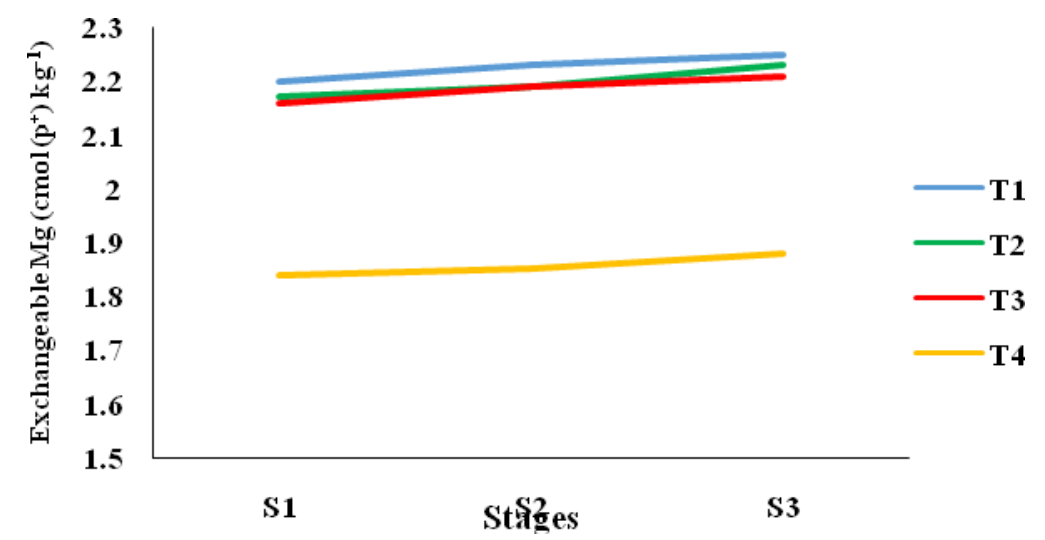

Fig.3c Exchangeable $\mathrm{Mg}\left(\mathrm{cmol}\left(\mathrm{p}^{+}\right) \mathrm{kg}^{-1}\right)$

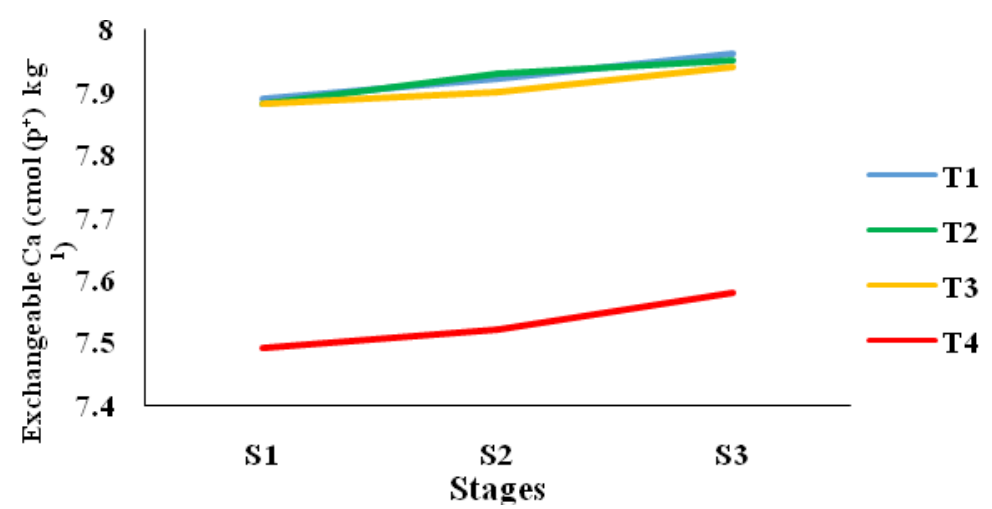

Fig.3b Exchangeable $\mathrm{Ca}\left(\mathrm{cmol}\left(\mathrm{p}^{+}\right) \mathrm{kg}^{-1}\right)$

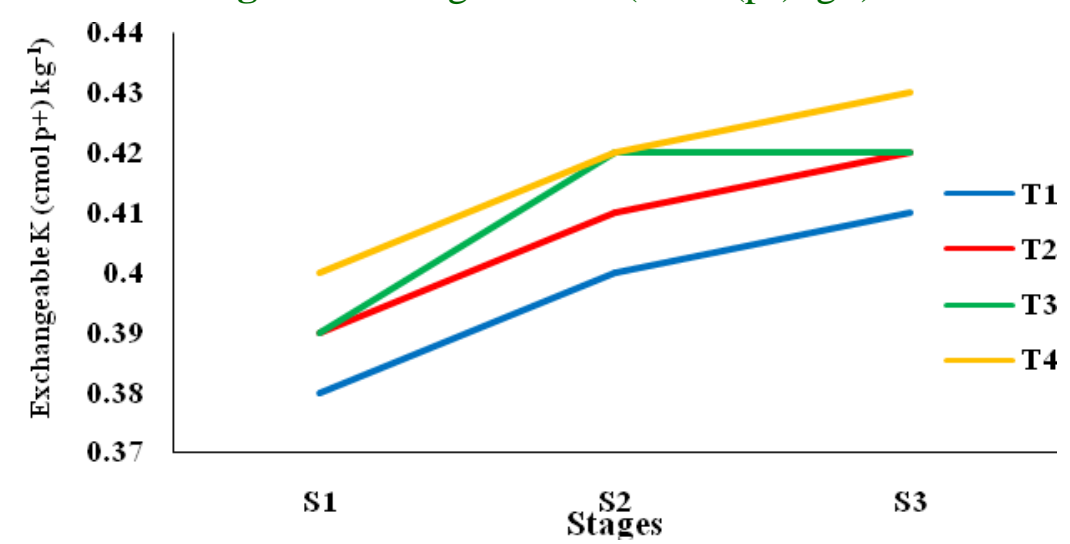

Fig.3d Exchangeable $\mathrm{K}\left(\mathrm{cmol}\left(\mathrm{p}^{+}\right) \mathrm{kg}^{-1}\right)$

$\left(\mathrm{S}_{1}: 30\right.$ DAS; $\mathrm{S}_{2}-60$ DAS; $\mathrm{S}_{3}$-at harvest stage $)$ 
Fig.4 Effect of lateral spacing on soil exchangeable sodium percentage in the subsurface drainage system

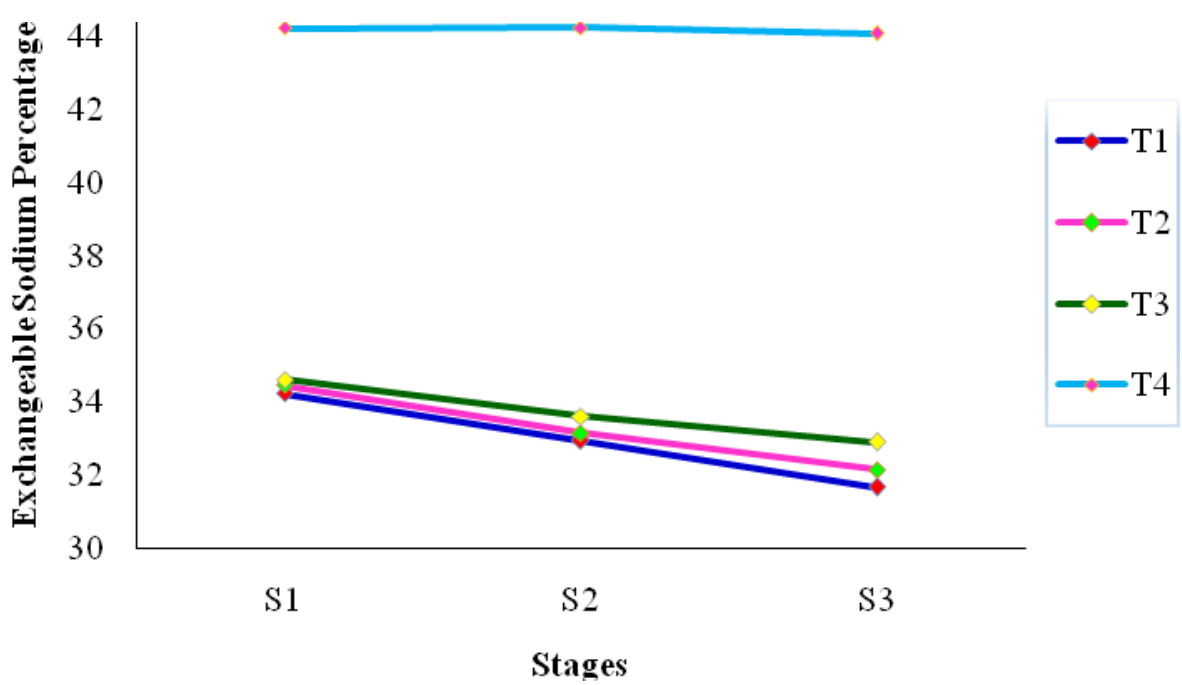

$\left(\mathrm{S}_{1}: 30\right.$ DAS; $\mathrm{S}_{2}-60$ DAS; $\mathrm{S}_{3}$-at harvest stage $)$

Fig.5 Effect of lateral spacing on maize yield $\left(\mathrm{kg} \mathrm{ha}^{-1}\right)$

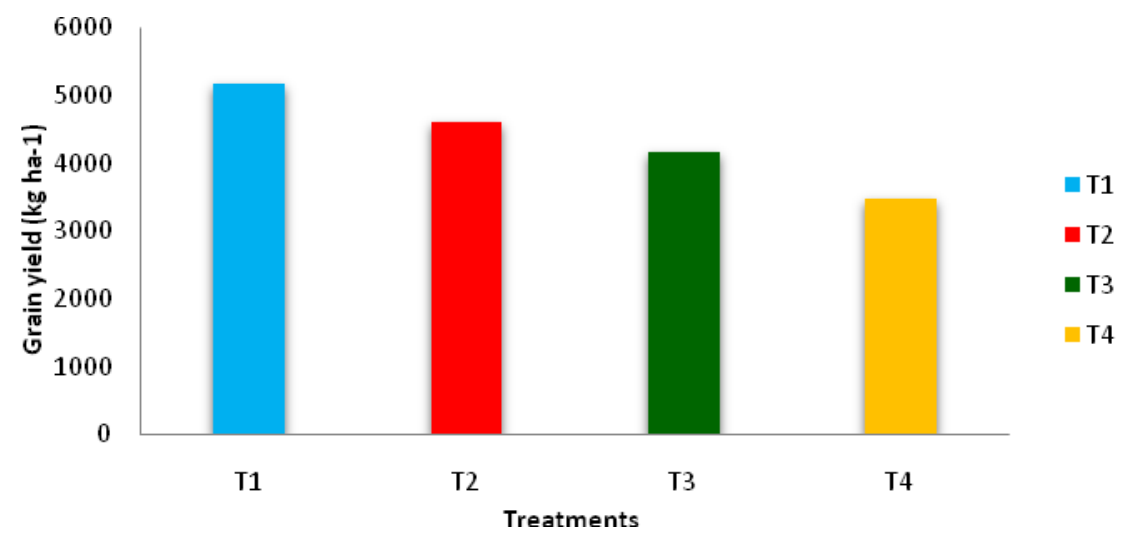

$\left(\mathrm{S}_{1}: 30\right.$ DAS; $\mathrm{S}_{2}-60$ DAS; $\mathrm{S}_{3}$-at harvest stage $)$

The highest cob length, maximum test weight, cob yield and grain yield was recorded in the drained field with $15 \mathrm{~m}$ lateral spacing followed by 20 and $25 \mathrm{~m}$ lateral spacing (Fig. 5). The increase was due to improvement in soil physical properties viz., infiltration rate, porosity and chemical properties (low $\mathrm{pH}$, EC, ESP) and improved nutrient availability in the drained field. Similarly, Abdel-Dayem and Ritzema (1990) reported an increased yield of many crops to a tune of 10 percent for rice, 48 percent for berseem, 75 percent for maize and more than 130 percent for wheat under subsurface drainage system. The increase was because of decreased soil salinity, improved air and water condition in 
crop root zones. The poor yield of maize in the undrained field due to poor soil physicochemical properties viz., shallow water table depth, high $\mathrm{pH}$, EC and ESP (Stieger and Feller, 1994; Samad et al., 2001 and Zhang et al., 2015), which limits the growth and development of crops in waterlogged saline-alkali soil.

In conclusion, the subsurface drainage system is a highly promising technology to overcome the adverse effect of waterlogging and salinealkali soil problem in the industrial effluent and canal water irrigated areas. The provision of the subsurface drainage system, readily leach the soluble salts from the soil layer through drainage water, which is a limiting factor for proper growth and development of plants in salt-affected soil. Further, the subsurface drainage system decreases the soil reaction $(\mathrm{pH})$, electrical conductivity and exchangeable sodium percentage under different lateral spacing in the drained field. The overall improvement in the soil physicochemical condition, increase in germination percentage, plant height, leaf length, leaf width and leaf area index of maize crop was observed, due to removal of a large amount of soluble salts, waterlogging free condition and increased nutrient availability in drained field, which favored the plant growth and development.

\section{Acknowledgments}

The authors are thankful to Department of Environmental Sciences, Tamil Nadu Agricultural University, Coimbatore and Tamil Nadu News Print and Paper Limited, Pugalur for the financial and logistics support to carrying out the research.

\section{References}

Ambast, S.K., S.K. Gupta and Singh, G. 2007. Agricultural Land Drainage.
Reclamation of waterlogged saline lands. Central Soil Salinity Research Institute, Karnal, India, p. 231.

Bahceci, I., and Nacar, A.S. 2009. Subsurface drainage and salt leaching in irrigated land in south-east Turkey. Irrig. Drain., 58: 346-356.

Bakker, D., M. Hamilton, G.J. Hetherington and Spann,R. 2010. Salinity dynamics and the potential for improvement of waterlogged and saline land in a Mediterranean climate using permanent raised beds. Soil Till. Res., 110 (1): 824.

Balusamy, A., C. Udayasoorian, T.R. Shanmugam, R.M. Jayabalakrishnan and Vinodhkumar, K. 2013. Environmental and socio economic impact of treated paper mill effluent irrigation in Karur district of Tamil Nadu. Madras Agric. J., 100 (special issue): $336-342$

Balusamy, A., and Udayasoorian,C.2016a. Effect of subsurface drainage system and amendments on soil quality parameters under waterlogged saline alkali soil. International Journal of Agriculture Sciences, 8 (63): 35523555.

Balusamy, A., and Udayasoorian, C. 2016b. Impact of subsurface drainage system and soil amendments on sunflower growth and yield under waterlogged saline alkali soil. Advances in Life Sciences 5(22): 10808-10811.

Bharambe, P. R., D.K. Shelke, G.S. Jadhava, V.G. Vaishnava and Oza, S.R. 2001. Management of salt-affected vertisol with subsurface drainage and crop residue incorporation under soybeanwheat cropping system. J. Indian Soc. Soil Sci., 49(1): 24-29.

Bhattacharya, A.K., and Michael, A.M. 2003. Land Drainage-Principles, Methods and Applications. Konark Publishers Pvt. Ltd, New Delhi. 
Chahar, B.R., and Vadodaria, G.P. 2008. Steady subsurface drainage of homogeneous soils by ditches. In: Proc. of the Institution of Civil EngineersWater Management 161, Issue WM6, pp.303-311.

DOI:

10.1680/wama.2008.161.6.303

Gopalakrishnan, M., and Kulkarni, S.A. 2007. Agricultural land drainage in India. Irrig. Drain., 56: 59- 67.

Grattan, S.R., and Oster, J.D. 2003. Use and reuse of saline-sodic waters for irrigation of crops. In: Crop production in saline environments: Global and integrative perspectives (Eds.) S.S. Goyal, S.K. Sharma and D.W. Rains. Haworth Press, New York, pp. 131-162.

Halliwell, D. J., K. M. Barlow and Nash, D.M. 2001. A review of the effects of wastewater sodium on soil physical properties and their implications for irrigation systems. Aust. J. Soil Res., 39:1259-67. DOI: 10.1071/SR00047

Hameed, S.M., and Udayasoorian, C. 1998. Changes in soil chemical properties and plant nutrient content under Eucalyptus irrigated with paper mill effluent and sludges in forest nurseries. In: Water World, 1998. Natl. sem. on applications of treated effluent for irrigation, held at Regional Engineering College, March 23, Trichy, pp. 38-49.

Hazarika, S., N.C. Talukdar, K. Borah, N. Barman, B.K. Medhi, D. Thakuria and Barooah, A.K. 2007. Long-term effect of pulp and paper mill effluent on chemical and biological properties of heavy textured acidic soil in Assam. J. Indian. Soc. Soil Sci., 55: 45-51.

Jackson, M.L., 1973. Soil Chemical Analysis. Prentice Hall of India (Pvt.) Ltd., New Delhi.

Kolekar, O.L., S.A. Patil, S.B. Patil and Rathod, S.D. 2011. Effect of different mole spacing's on the yield of summer groundnut. Intl. J. Agric. Engg., 4(1):
82-85.

Kumar, V., and Chopra, A.K. 2011. Alterations in physico-chemical characteristics of soil after irrigation with paper mill effluent. J. Chem. Pharm. Res., 3 (6):7-22.

Kumar, V., A.K. Chopra, S. Kumar, J. Singh and Thakur, R.K. 2015. Effects of pulp and paper mill effluent disposal on soil characteristics in the vicinity of Uttaranchal pulp and ppaper mill, Haridwar (Uttarakhand), India. Intl. J. Agric. Sci. Res., 4(6):117-125.

Pradeep, H.M., N.S. Hebsur, S.K. Gali and Koti,R.V. 2005. Effect of subsurface drainage and amendments on soil physical and chemical properties of black soil of Ghataprabha command area. Karnataka J. Agric. Sci., 18 (3): 953-958.

Prasad P.R.K., D. Srinivas, T.V. Satyanarayana, S.R. Chandra, G.S. Rao, B.M. Rao and Srinivasulu, A. 2007. Reclamation saline and waterlogged soils in Mutluru channel command of Krishna Western Delta, Andhra Pradesh state, India. In: $58^{\text {th }}$ ICID meeting and The USCID $4^{\text {th }}$ Intl. conf. on irrigation and drainage, $30^{\text {th }}$ September to $6^{\text {th }}$ October, held at Sacramento Convention Center, California-USA.

Rakesh, K., R.D. Singh and Sharma, K.D. 2005. Water resources in India. Curr. Sci., 89:794-811

RamanaRao, K.V., and Bhattacharya, A.K. 2001. Salinity distribution in paddy root zone under subsurface drainage. Agric. Water Manage., 48(2): 169-178.

Ritzema, H.P., 2009. Drain for gain making water management worth its salt. Subsurface drainage practices in irrigated agriculture in semi-arid and arid regions, Ph.D. Thesis, Wageningen University and UNESCO-IHE Delft.

Ritzema, H.P., and Schultz, B. 2011. Optimizing subsurface drainage 
practices in irrigated agriculture in the semi-arid and arid regions: experiences from Egypt, India and Pakistan. Irrig. Drain., 60: 360-369.

Samad, A., C. A. Meisner, M. Saifuzzaman and Van Ginkel, M. 2001. Waterlogging tolerance. In: Application of physiology in wheat breeding. (Eds.) M.P. Reynolds, J.I. Ortiz-Monasterio and A. McNab, CIMMYT- Mexico, pp.136144.

Saxena, K.L., S.D. Makhijani and Ramakrishnan, S.K. 1978. Settling studies on pulp and paper mill wastewater. Indian J. Environ. Hlth.,20: 273-283.

Sharma, V., K. Umesh, Garg and Arora,D. 2014. Impact of pulp and paper mill effluent on physico-chemical properties of soil. Archives Applied Sci. Res., 6(2): 12-17.

Sousa, C.H.C., F.L.B. Silva, C.F. Lacerda, R.N.T. Costa and Gheyi, H.R. 2011. Installation of a subsurface drainage system in a saline-sodic soil cultivated with coconut in pentecoste -ceará. Revista Brasileira de Agricultura Irrig., 5(1): 16-23.

Stieger, P.A. and Feller, U. 1994. Nutrient accumulation and translocation in maturing wheat plants grown on waterlogged soil. Plant Soil, 160: 87-95.

Thomas, G.W., 1982. Exchangeable cations. In: Methods of soil analysis, Part 2 Chemical and microbiological properties, (Ed.) A.L. Page, $2^{\text {nd }}$ edition, Agronomy, pp. 159-165.

Udayasoorian, C., P. Jothimani and Prabu, P.C. 2003. Impact of treated paper mill effluent and organic amendments on bhendi. J. Environ. Res., 13 (2):50-56.

Udayasoorian, C., P.C. Prabu and Mini, K. 2004. Influence of composted bagasse pith and treated paper mill effluent irrigation on groundnut. Madras Agric. J., 91: 126-129.

Yu, S., J. Liu, E. Eneji, L. Han, L. Tan and Liu,H. 2016. Dynamics of soil water and salinity under subsurface drainage of a coastal area with high groundwater table in spring and rainy season. Irrig. Drain., 65(3): 360-370.

Zhang, Y., X. Song, G. Yang, Z. Li, H. Lu, X. Kong, A.E. Eneji and Dong, H. 2015. Physiological and molecular adjustment of cotton to waterlogging at peakflowering in relation to growth and yield. Field Crops Res., 179: 164 -172.

\section{How to cite this article:}

Arumugam Balusamy, Chinniah Udayasoorian and Rajamani Jayabalakrishnan. 2019. Effect of Subsurface Drainage System on Maize Growth, Yield and Soil Quality. Int.J.Curr.Microbiol.App.Sci. 8(02): 1206-1215. doi: https://doi.org/10.20546/ijcmas.2019.802.140 